\title{
Animation creativity as a factor in the development of children's giftedness
}

\author{
Natalia Sergeevna Murodhodjaeva ${ }^{1 *}$, Sergey Alexandrovich Averin ${ }^{1}$, Andrey V. Koptelov ${ }^{2}$, \\ Svetlana Ivanovna Karpova ${ }^{1}$, and Elena Ivanovna Sukhova ${ }^{1}$ \\ ${ }^{1}$ Moscow City University, Institute of Pedagogy and Psychology of Education, Moscow, Russia \\ ${ }^{2}$ Sam Houston State University, College of Education, Texas, USA
}

\begin{abstract}
The main premise of the study is the objective need to find new means for the development of children's personality in the modern educational process. Scientific and technological progress, the active use of technology and gadgets by children, even young children, the expansion of the use of distance learning and communication, artificial intelligence, and social networks are the realities in which we already live. Therefore, high relevance is gained by the means that are based on information technologies on the one hand but have the potential for the development of children's personality on the other. What can be considered as one such instrument is animation creativity of children that involves the process of children jointly composing, creating, and discussing a cartoon of their own making. The assumption of the potential effectiveness of animation creativity as a means of developing children's giftedness is based on the fact that in the process of joint creation of a cartoon, children show and develop several abilities as they create the script, images of characters, their characters and appearances, as they are involved in filming, montage, editing, as well as the presentation and promotion of the finished animated film. Children interact with one another and with technical devices, learn to listen to and hear each other, substantiate their opinion, carry the responsibility for collective work, distribute responsibilities between each other, and bring the creative idea to fruition in the finished product. The goal of the study is to conduct an empirical study to determine the effect of the author's children's animation technique on the development of figurative thinking in older preschool-age children. Methods: observation, conversation, measurement, creative tasks, comparative analysis of experimental data.
\end{abstract}

Keywords: animation creativity, children's author's animation technique, STEM education, children's giftedness, figurative thinking.

\section{Introduction}

Premises of the study: An integral component of the development of children's giftedness is the creation of conditions in which a child develops research abilities and develops a system of value attitudes to independent creative search. Such conditions include all components of

* Corresponding author: murodhodjaeva@yandex.ru 
a development-inducing educational environment (informational, social, technological, spatial-objective).

In this regard, we can assume the potential effectiveness of STEM education $(S$-science, $T$ - technology, $E$ - engineering, $M$ - mathematics) in the development of children's giftedness as STEM education is aimed at the systemic development of thinking, research abilities, and creativity of children in the process of joint scientific and technological creativity. It is also important to emphasize that STEM education implies a process of collaborative creation, playing, presentation, discussion, and subsequent revision of children's own projects or models. In Russian pedagogy, STEM education technologies are fully reflected in the partial modular program "STEM education of preschool and elementary school children" (authors - T.V. Volosovets, V.A. Markova, S.A. Averin; the authors of educational modules for primary general education level - S.A. Averin, N.S. Murodkhodzhaeva, M.A. Romanova, A. Serebrennikova, etc.) [1-3]. In three years (end of 2017 - beginning of 2020), the program was tested in 294 preschool educational organizations of the Russian Federation that received the official status of innovative platforms of the Russian Academy of Education [3, 4]. An integral part of this program is the educational module "Cartoon studio", in the course of which children compose the plot and scenario of a cartoon, create characters and scenery, shoot and edit their own cartoons, and watch and discuss their own cartoons. In other words, the essence of the method of children's author's animation lies in children's collaborative animation creativity rather than the use of a pre-made cartoon in the educational process.

The modern works of Russian researchers (S.A. Averin, V.A. Markova, N.S. Murodkhodzhaeva, Iu.A. Serebrennikova, Romanova, O.V. Tsaplina, etc.) reveal the positive influence of animation activity on the comprehensive harmonious development of a child from an early age $[5,6]$.

Despite the existence of works substantiating the positive influence of animation activities on the cognitive, creative, artistic-aesthetic, and social development of children, no special research has been conducted on the influence of animation activities on the development of giftedness in preschool children.

Currently, in the context of the problem of developing children's giftedness, the search for effective educational methods of implementing the potential of animation activities to develop the structural components of giftedness, the predominant among which is figurative thinking, is a priority [7].

Hypothesis: the realization of the method of children's author's animation in the educational practice will promote the development of figurative thinking in preschool and younger school-age children.

The goal of the study: to conduct an empirical study to determine the effect of the method of children's author's animation on the development of figurative thinking in older preschool children.

Objectives: to develop criteria and diagnostic tools to assess the level of development of figurative thinking in 7-year-old children; to implement the method of author's animation by teaching older preschool children the educational program "Cartoon studio "I create the world" [8]; to conduct a comparative analysis of the results of the ascertaining and control diagnostics to identify the dynamics in the level of figurative thinking in older preschool children.

\section{Methods}

The main method of the study is a pedagogical experiment including the ascertaining, formative, and control stages, the set of empirical methods used in the course of the 
experimental work includes observation, conversation, measurement, creative tasks, and comparative analysis of experimental data.

The pilot study was conducted between 2018 and 2019 in preschool departments of Moscow general education schools № 883, 1210, 1216, 1430, 1523. The experiment involved 123 children of older preschool age, the average age of the subjects was 6 years 2 months. The deployed sampling method was a random selection of natural groups.

To assess the level of development of figurative thinking in children, we developed a criteria-diagnostic toolkit including standardized techniques of R.I. Bardina, O.M. Diachenko, A.F. Luriia, and R.S. Nemov (Table 1). An important criterion in the selection of these techniques was the possibility of their use by educators with no special psychological education [9].

Table 1. Criterion-diagnostic tools assessing the level of development of figurative thinking in preschoolers.

\begin{tabular}{|c|c|c|c|c|}
\hline$\#$ & Criteria & Indicators & Assessment method & Author \\
\hline 1 & $\begin{array}{l}\text { Visual analysis } \\
\text { and synthesis }\end{array}$ & $\begin{array}{c}\text { Assessment of the level } \\
\text { of development of } \\
\text { visual-figurative } \\
\text { thinking }\end{array}$ & $\begin{array}{c}\text { "Kakie predmety } \\
\text { spriatany v risunkakh?" } \\
\text { ["What objects are } \\
\text { hidden in the } \\
\text { pictures?"] }\end{array}$ & R.S. Nemov \\
\hline 2 & $\begin{array}{l}\text { Orientation } \\
\text { actions }\end{array}$ & $\begin{array}{l}\text { Examination of the } \\
\text { ability to use schematic } \\
\text { representations for } \\
\text { orientation in space }\end{array}$ & $\begin{array}{l}\text { "Skhematizatsiia" } \\
\text { (Labirint) } \\
\text { ["Schematization" } \\
\text { (Labyrinth) }\end{array}$ & R.I. Bardina \\
\hline 3 & Figurative coding & $\begin{array}{l}\text { Assessment of the } \\
\text { ability to translate text } \\
\text { into the sign-symbolic } \\
\text { language (coding) }\end{array}$ & $\begin{array}{l}\text { "Piktogramma" } \\
\text { ["Pictogram"] }\end{array}$ & A.F. Luriia \\
\hline 4 & $\begin{array}{l}\text { Correlation of the } \\
\text { scheme and the } \\
\text { real situation }\end{array}$ & $\begin{array}{l}\text { Diagnostics of the level } \\
\text { of development of } \\
\text { perception and } \\
\text { correlation of the shape } \\
\text { of objects with the } \\
\text { provided samples } \\
\text { (etalons) }\end{array}$ & "Etalony" ["Etalons"] & $\begin{array}{c}\text { O.M. } \\
\text { Diachenko }\end{array}$ \\
\hline
\end{tabular}

At the formative stage of the study, 7-year-old children were taught using the method of children's author's animation by means of the modular educational program "Cartoon studio "I create the world" [10].

Over 80 game tasks focused on the development of visual thinking in 6-7-year-old children were developed and implemented in practice.

As an example, we provide the following types of tasks:

- to film a mini-cartoon about how a ball can roll and how a cube can "move" with children. A basis for the story about the ball and cube shapes can be the "Kolobok" fairy tale the main character of which has to roll around;

- to prepare scripts of small cartoons with "characters" representing various sensory etalons. For instance, how three balls of different sizes "turn into" a snowman, how flowers of different colors bloom, etc.;

- to film a small cartoon in which objects "disappear" and "appear" to watch it with students and stimulate their comments: "one", "none", "many". For example, there may be a 
different number of frogs in a lake - "one", "many", - and then they jump into the water and disappear - "none".

\section{$3 \quad$ Results}

The comparative analysis of the results of the study of the level of development of figurative thinking in children at the ascertaining stage is presented in Table 2.

Table 2. Mean values of the figurative thinking development criteria in older preschool children at the ascertaining and control stages of the pilot experiment.

\begin{tabular}{|l|c|c|}
\hline \multirow{2}{*}{ Figurative thinking development criteria } & \multicolumn{2}{c|}{ Mean values } \\
\cline { 2 - 3 } & Ascertaining stage & Control stage \\
\hline Visual analysis & 3.05 & 7.03 \\
\hline Visual synthesis & 3.34 & 7.04 \\
\hline Orientation actions & 3.89 & 7.79 \\
\hline Figurative coding & 3.16 & 7.25 \\
\hline Correlation of the scheme and the real situation & 4.15 & 8.15 \\
\hline
\end{tabular}

To confirm the effectiveness of the empirical study, we used a comparative analysis of data on the criteria of the development of figurative thinking in children at the ascertaining and control stages using Student's t-test.

Result: $t_{\text {Emp }}=13.1$

Critical values

\begin{tabular}{|c|c|}
\hline \multicolumn{2}{|c|}{$\mathrm{t}_{\mathrm{Cr}}$} \\
\hline $\mathrm{p} \leq 0.05$ & $\mathrm{p} \leq 0.01$ \\
\hline $\mathbf{2 . 3 1}$ & $\mathbf{3 . 3 6}$ \\
\hline
\end{tabular}

\section{Significance axis}

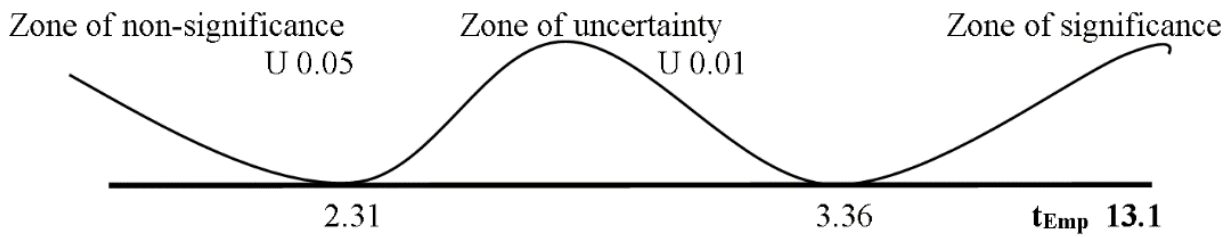

Fig. 1. Significance axis: the obtained empirical value of $t_{E m p} 14.4$ is in the zone of significance.

Significant differences in the values of the initial and final levels of development of figurative thinking in children allow us to conclude on the effectiveness of the author's animation technique. 


\section{Discussion}

Children's animation creativity is a process of children collectively composing and gradually realizing their own creative idea which results in an author's cartoon. The organization of this process in the educational organization is reflected in the technique of children's animation [6].

Practice shows that this type of creative activity has great educational potential allowing to successfully solve a variety of tasks (in education, upbringing, and correction and development) $[11,12]$. Specialists indicate that children's animation technologies represent a specific type of the creative IT industry with great prospects for development in education.

Of particular scientific interest is the problem of realizing the potential of animation creativity for the development of giftedness in children and adolescents [13-15].

Another important condition for the success of this solution is the professional readiness of kindergarten and school teachers to develop children's giftedness using the means of STEM education.

\section{Conclusion}

The analysis of the results of the conducted study allows concluding that the children's author's animation that presents a significant component of STEM education has sufficient potential for the development of children's giftedness. The study supports the hypothesis that the method of author's animation based on a system of creative tasks is an effective instrument for the development of figurative thinking as the predominant component in the structure of childhood giftedness in older preschool children.

\section{References}

1. M.A. Romanova, Innovation in Education, 2, 113-125 (2011)

2. Iu.A. Serebrennikova, Podgotovka pedagogov k realizatsii STEM-obrazovaniia [Preparation of teachers for the implementation of STEM-education], in Collection: Upravlencheskie resheniia aktualnykh problem sovremennogo obrazovaniia. Materialy mezhdunarodnogo kruglogo stola, 136-142 (2019)

3. T.V. Volosovets, V.A. Markova, S.A. Averin, STEM-obrazovanie detei doshkolnogo i mladshego shkolnogo vozrasta. Partsialnaia modulnaia programma razvitiia intellektualnykh sposobnostei [STEM-education of pre-school and primary school children. Partial modular program for developing intellectual abilities] (BINOM, Laboratoriia znanii, Moscow, 2019)

4. F.I. Vakhovskii, N.V. Kabanova, V.A. Markova, T.A. Trifonova, "STEM-obrazovanie detei doshkolnogo i mladshego shkolnogo vozrasta": Otchet o realizatsii partsialnoi modulnoi programmy razvitiia intellektualnykh sposobnostei v protsesse poznavatelnoi deiatelnosti i vovlecheniia v nauchno-tekhnicheskoe tvorchestvo v obrazovatelnykh organizatsiiakh Krasnodarskogo kraia ["STEM-education of preschool and primary school children": Report on the implementation of a partial modular program for the development of intellectual abilities in the process of cognitive activity and involvement in scientific and technical creativity in educational institutions of Krasnodar Krai] (OLMA-PRESS, Krasnodar, 2020)

5. S.I. Karpova, N.S. Murodkhodzhaeva, O.V. Tsaplina, A.P. Kaitov, Bulletin of Tomsk State Pedagogical University, 6(212), 46-56 (2020) 
6. S. Averin, N. Murodhodjaeva, M.Romanova, Yu. Serebrennikova, A.V. Koptelov, SHS Web of Conferences, 79, 01002 (2020). https://doi.org/10.1051/shsconf/20207901002

7. A. Savenkov, S.I. Karpova, E.I. Sukhova, Psychology And Education. An Interdisciplinary Journal, 55(2), 74-84 (2018)

8. T.D. Savenkova, Bulletin of the Moscow City University. Series: Pedagogy and Psychology, 3(41), 47-53 (2017)

9. S.A. Averin, E.A. Alisov, N.S. Murodhodjaeva, L.E. Osipenko, I.A. Noskov, O.V. Tsaplina, International Journal of Engineering and Technology(UAE), 7(4.7), 276-282 (2018)

10. V. Punchyk, N. Murodhodjaeva, S. Averin, L. Varanetskaya, K. Piatrutskaya, SHS Web of Conferences, 79, 01013 (2020). https://doi.org/10.1051/shsconf/20207901013

11. E.A. Pogrebinskaya, N.Y. Zubenko, N.S. Murodhodjaeva, International Journal of Civil Engineering and Technology, 9(11), 2444-2451 (2018)

12. A.P. Sukhonosov, O.A. Korneeva, Organizatsiia vzaimodeistviia subektov obrazovatelnykh otnoshenii pri psikhologicheskom soprovozhdenii innovatsionnykh programm i tekhnologii [Organization of interaction of the subjects of educational relations in the psychological accompaniment of innovative programs and technologies], in Proceedings of the $6^{\text {th }}$ All-Russian Scientific and Practical Conference "Rebenok v sovremennom obrazovatelnom prostranstve megapolisa" [A child in the modern educational space of a metropolis], Moscow City University, April 2019, Moscow, Russia, 54-58 (2019)

13. A.V. Maltese, C.S. Melki, H.L. Wiebke, Science Education, 98(6), 937-962 (2014). https://doi.org/10.1002/sce.21132

14. I.A. Vinogradova, E.V. Ivanova, T.D. Savenkova, O.V. Tsaplina, European Journal of Contemporary Education, 6(4), 808-816 (2017)

15. J.M. Breiner, HS. Sarkness, C.C. Johnson, C.M. Koehler, School Science and Mathematics, 112(1), 3-11 (2012). https://doi.org/10.1111/j.1949-8594.2011.00109.x 